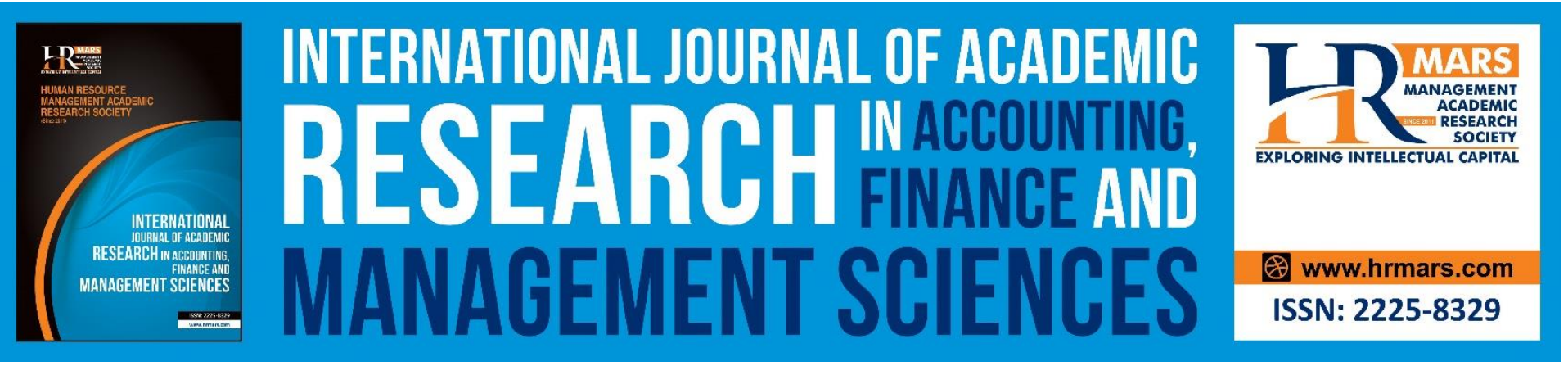

\title{
Corporate Voluntary and Mandatory Disclosure: Evidence from Georgian Companies
}

\section{Metin Mercan}

To Link this Article: http://dx.doi.org/10.6007/IJARAFMS/v11-i1/8480

DOI:10.6007/IJARAFMS /v11-i1/8480

Received: 15 January 2021, Revised: 16 February 2021, Accepted: 28 February 2021

Published Online: 24 March 2021

In-Text Citation: (Mercan, 2021)

To Cite this Article: Mercan, M. (2021). Corporate Voluntary and Mandatory Disclosure: Evidence from Georgian Companies. International Journal of Academic Research in Accounting Finance and Management Sciences, 11(1), 423-438.

\section{Copyright: (C) 2021 The Author(s)}

Published by Human Resource Management Academic Research Society (www.hrmars.com)

This article is published under the Creative Commons Attribution (CC BY 4.0) license. Anyone may reproduce, distribute, translate and create derivative works of this article (for both commercial and non-commercial purposes), subject to full attribution to the original publication and authors. The full terms of this license may be seen at: $\underline{\text { http://creativecommons.org/licences/by/4.0/legalcode }}$

Vol. 11, No. 1, 2021, Pg. 423 - 438

Full Terms \& Conditions of access and use can be found at http://hrmars.com/index.php/pages/detail/publication-ethics 


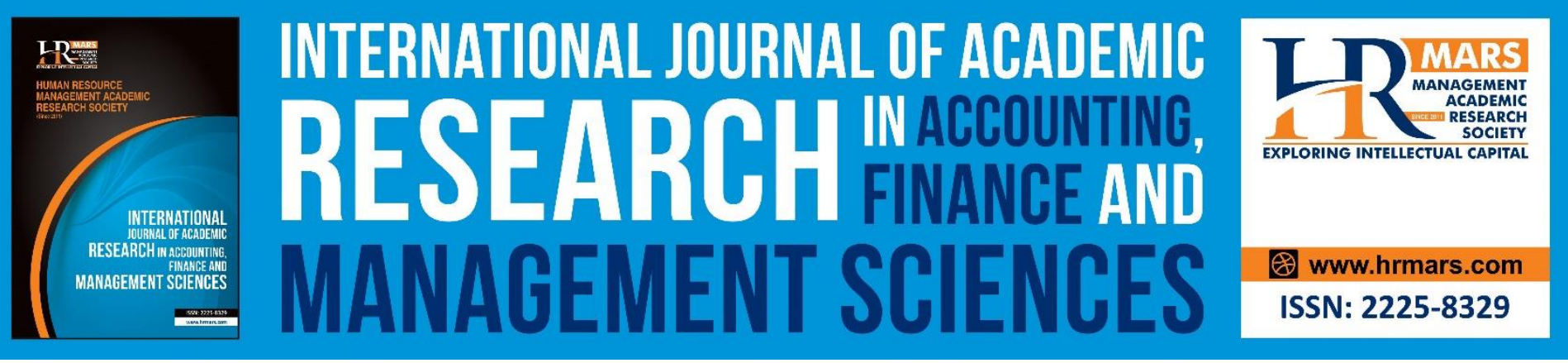

\title{
Corporate Voluntary and Mandatory Disclosure: Evidence from Georgian Companies
}

\author{
Metin Mercan \\ PhD, Finance Professor, Faculty of Business and Technologies, International Black Sea University, \\ Tbilisi, Georgia
}

\begin{abstract}
The main idea in current paper is to check the disclosure level in listed Georgian companies and to assess the speculated effect of various company peculiarities amount of voluntary or mandatory disclosure. A disclosure list containing 35 items were established to check the amount of disclosure in 50 companies' annual financial statements in 2018. The relationship between the amount of disclosure and various firm peculiarities was analyzed by the means of Ordinary Least Square regression. The outcomes demonstrated a positive association between voluntary information level and the independent variables such as profitability of firms, type of industry and board size. However unexpectedly, leverage was found to have negative significant association with the voluntary disclosure information.
\end{abstract}

Keywords: Voluntary Disclosure, Mandatory Disclosure, Dindex, Financial Reporting, Transparency, Georgia

\section{Introduction}

In the recent years, companies in accounting, finance and non -financial companies acknowledge the importance of mandatory or voluntary disclosure. Disclosure provides companies to improve the business environment and keeps investors from any kind of financial crimes or fraudulent situation. Voluntary or mandatory disclosure provides more transparent and accountable information about the organizations existing in Georgia, which open the ways for the further investments in the country. The foreign investors need more public information about the firms' annual reports or activities for their confidence to make investments. As it is well defined that annual reports are essential parts of financial communication strategy to attract and thus retain investors.

Recent increasing interest in disclosures have been improved in nowadays capital market. The prevailing concerns about the globalization and the stock market keeping standards have enlarged the worry and paid more attention to participants in capital market for increased data above the least legal needs so that it helps decision-makers to make knowledgeable decisions (Berradino, 2001). Companies have done their best to encourage their management procedures and increase 
INTERNATIONAL JOURNAL OF ACADEMIC RESEARCH IN ACCOUNTING, FINANCE AND MANAGEMENT SCIENCES

Vol. 11, No. 1, 2021, E-ISSN: 2225-8329 @ 2021 HRMARS

collective responsibilities. Corporate management is described as the plan by which the organizations are organized and managed (Cadbury, 1992).

The studies of Singhvi and Desai (1971) illustrated that accounting quality and quality of information presented in financial statements of companies significantly effects on investor decision making process and their choices. Other researches held in Sweden explained the same important relationship between company, control variables and voluntarily disclosure (Cooke, 1989).

In many countries' disclosure is regulated by the securities law. However, many companies voluntarily disclose and more information about companies are moderated by the law. Such kind of the regulations were basically helped companies to avoid financial scandals and crimes. (Brogia,2005). A number of studies have been held about releasing information publicly. Most of them focus on main determinants of disclosure and the firm's specific characteristics and, such as: Corporate ownership, ownership dispersion, dependent/ independent directors, profitability indicators, corporate Governance Index, board size, age of firms, firm size, leverage and auditor size (Uyar et al., 2013).

Poshakwale and Courtis (2005) examined the relationship between cost of equity and the level of disclosure. They found that the lower level disclosure causes the low level of confidence of investors, which affect its side causes the lower dividend payouts, and finally reduces the cost of equity capital.

Francis et al. (2005) applied 34 countries as a sample for companies which are externally financed. These companies disclosed extremely a lot information about them charges lower cost of external financing that causes reduced cost of debt and equity capital. McKinnon \& Dalimunthe (1993) investigated economic motivation of voluntary disclosure in Australian listed companies, their results have shown that voluntary disclosure aggressively reply to the combination of ownership.

Simon and Wong (2001) studied Hong Kong listed companies to find association between the corporate governance and voluntary disclosure. Their findings indicated that enhanced, improved management of board of directors could encourage voluntary disclosure of information

The rest of paper follows as methodology and data collection and model and equations are explained, lastly findings are explained.

\section{Methodology and Data Collections}

The sample of the research includes Georgian companies from both manufacturing and service types. Annual reports of the companies are collected from Georgian Stock Exchange. Sample of companies initially 56 companies. But some companies do not provide enough data (missing of some necessary information). Hence, final sample in the theses includes 50 companies. I also asked companies to provide annual reports of those companies by the e-mail. Unexpectedly none of these companies replied positively. Having downloaded the annual reports of companies for the year of 2018, I have checked the financial position, thus the level of disclosure of 50 Georgian Joint stock companies, those covered several industries, particularly manufacturing, construction-repairing, cement, agriculture (they are marked as \# 1); service, electricity, communication (marked as \# 0).

\section{Dependent Variable}

The main goal of study was to carefully choose the data those are believed to appear in annual financial statements which would be useful in measuring the disclosure level. Such data 
should be voluntarily revealed and at the same time it should be significant for the shareholders as well. That is why disclosure item are chosen carefully. It is very hard to assess the nature of disclosure index in Georgia. There are a number of institutions those estimate disclosure quotation in various countries. None of them exist in Georgia.

Formulated Disclosure index was used to benchmark assessing the amount of disclosure. It is used to calculate the data enclosed in the annual statements of the corporations. The formulation of the disclosure index depends on the data given in the annual financial statements prepared for the shareholders from the side of the companies. Financial statements act as a broadly approved alternate for the amount of disclosure supplied by the company. Knutson (1992) considered the annual report as the most important of all the documents, according to him all other financial reports were helpful, secondary and auxiliary to it. It is likely that there are various means for revealing information publicly, for example TV broadcasts, magazines and journals. Nevertheless, confidence of such means of voluntary disclosure suggest some kind of complications.

The items of data are counted by dichotomous policy which puts a number of 1 if company reveals an item in the annual reports and puts a number of 0 if it does not. Entire disclosure index of each company is calculated as a part of the entire disclosure number to the maximum potential disclosure index of companies. Correspondingly the disclosure index (DINDEX) was computed as follows:

Where:

$$
\text { DINDEX }=\sum_{j=1} \quad \frac{d j}{n}
$$

$\mathrm{d}_{\mathrm{j}}$ is 1 when the item $\mathrm{j}$ is disclosed

0 when the item $\mathrm{j}$ is not disclosed

$\mathrm{n}$ is the number of items

Hence DSCORE=Log (DINDEX/1-DINDEX) are have applied as the dependent variable in this paper.

$\mathrm{DSCORE}=\log \left(\frac{\text { VDINDEX }}{1-V D I N D E X}\right)$ is used as the dependent variable in the all models.

\section{Independent / Explanatory Variables}

A company's disclosure level can be impacted by perceptive, behavioral, financial, economic, governmental, constitutional, corporate and by some other determinants. It is affected by the firm characteristics as well. In this paper, focus of disclosure depends primarily on a set of variables collected from financial data that is reachable in their annual reports.

Independent variables can be categorized in two basic characteristics; they are: Corporate governance related variables and firm specific characteristics (Jensen and Meckling,1976); the first variables included in the paper as follows: Firm size, Leverage, Firm age, Profitability, Liquidity, Sales, return on equity and variables for measuring corporate governance are as follows: Independent directors, Audit size, Ownership structure, Board size Industry type.

\section{Model of Equations and Development}

Wallace et al. (1994) used a matched-pair analytical investigation to evaluate the distinction among the amount of average disclosure of various examples. Cross sectional regression analysis was recommended by Chow and Wang-Borne (1987). Lang and Lundholm (1993) and Wallace et. al. (1994) introduced an ordinary least square (OLS) after converting repetitive variables into a list of 
INTERNATIONAL JOURNAL OF ACADEMIC RESEARCH IN ACCOUNTING, FINANCE AND MANAGEMENT SCIENCES

Vol. 11, No. 1, 2021, E-ISSN: 2225-8329 ๔ 2021 HRMARS

numbers. Another paper of Camfferman and Cooke (2002) reinforced application of unranked OLS rather than the ranked one.

Taking into consideration the above-mentioned views current research supports usage of unranked OLS. Ordinary Least Square regression analyze was applied in this paper, to check the association among specific-related explanatory variables and the amount of disclosure. As a result, the subsequent model is provided:

Ordinary Least Square (OLS) and Two-Stage- Least Squares (2SLS) regressions are employed in the most papers to see relations between voluntary disclosure level and the explanatory variables like many other studies in the emerging countries, developed countries (Uyar et al., 2013; Patelli and Prencipe, 2007). In the regression models below I tested the Durbin-Wu-Hausman Test for endogeneity problems for variables. Endogenity is a problem explained as if one or more of explanatory variables has a correlation with error terms. Not any endogenous problems in the variables are seen. To employee endogeneity problem, I also collected two more variables like owner's equity and net income which mostly effect on ASSETS and SALES variables not related with error term and dependent variable (DSCORE). Result of $P$ value $(0.645,0.458)$ were greater than 5 level and 10 level significance. I accept the null hypotheses ( $N_{0}$ : variables are exogenous), therefore OLS will be consistent estimates in my paper. If there is endogeneity, there should be arranged some instrumental variables that are association with explanatory variables, but not with dependent variables and error term of main equations. Instrumental variables are not needed to correlate with neither exogenous variables and error term. In order to test endogeneity, t-test of residuals are used in all in regression models. Accepting the null hypotheses means that the properties of endogenous equation is biased and instrumental methods of equation should be employed. The same instrumental variables are used for ASSETS and SALES, because there are high and significant correlation between these two variables.

Ownership diffusion is difficult to calculate in Georgia. Because many companies don't report ownership structure of their company in the absence of disclosure requirement and capital market did not develop well yet, therefore there are not much individual ownership of shares in Georgia. Additionally, Georgian companies like secrecy and feels afraid of other factors. Consequently, I only managed to measure a few firm's proportion of shares hold their main owners. As a result, mentioned above, ownership diffusion and institutional ownership are omitted in my regressions.

The reasons mentioned above consequently force me to implement Ordinary Least Square (OLS) regressions. As table 4 shows Pearson correlation matrix and evidence the multicollinearity problem between ASSETS and SALES, ASSETS and BSIZE, therefore I didn't use these variables in the same model. As a result, four different models are provided:

$D S C O R E=\beta_{0}+\beta_{1} S A L E S+\beta_{2} R O E+\beta_{3} L E V E R+\beta_{4} A U D I T O R+\beta_{5} B S I Z E+\beta_{6} I N D I R+\beta_{7} L A G E+\beta_{8} X 8+\beta_{9} C U R R A T I O+e$ $D S C O R E=\beta_{0}+\beta_{1} A S S E T S+\beta_{2} R O E+\beta_{3} L E V E R+\beta_{4} A U D I T O R+\beta_{5} B S I Z E+\beta_{6} I N D I R+\beta_{7} L A G E+\beta_{8} X 8+\beta_{9} C U R R A T I O+$ e

DSCORE $=\beta_{0}+\beta_{1}$ SALES $+\beta_{2} R O E+\beta_{3}$ LEVER $+\beta_{4} A U D I T O R+\beta_{5} B S I Z E+\beta_{6} I N D I R+\beta_{7} L A G E+\beta_{8} X 8+\beta_{9} C U R R A T I O+e$ Where:

$$
\text { DSCORE }=\log \left(\frac{\text { VDINDEX }}{1-V D I N D E X}\right)
$$

Where $Y$ is disclosure Index level (DINDEX) and VDINDEX is the ratio of total items disclosed to maximum score of disclosure index for every companies in the sample;

- ASSETS=Total assets; 
- LEVER= total liabilities over total assets;

- SALES=Total sales revenue;

- $\mathrm{ROE}=$ net income divided by total equity;

- LAGE= firm age;

- CURRATIO= Liquidity ratio measures as current assets divided by total assets;

- INDIR =Part of independent directors on the board;

- $\mathrm{BSIZE}=$ number of board members;

- $A U D I T O R=$ dummy variable for audit size, that is scored as 1 for big 5 and 0 if not

- INDUST= Industry type

\section{Firm Specific Characteristic}

Firm Size

The common hypothesis is that a firm's disclosure process is correlated with its size. Mainly, disclosing detailed information is relatively less expansive for big companies because they are supposed to report such data for inner intention. But smaller companies may be afraid to state detailed information that may put them at an aggressive disadvantage.

In Georgia, the bigger firms with a huge amount of turnover, those are financed either locally or internationally, has to disclose information publicly by avoiding financial fraudulent situation. resulting hypothesis is:

H1: There is an important positive correlation between the firm capacity and the amount of transparency.

Leverage

A largely accepted suggestion is that the companies with high leverage are obliged to reveal data for fulfilling the requirements of customers for information. Therefore, leverage may be positively related to the amount of disclosure.

In Georgia information disclosure is important for the companies those have high rate of leverage. Creditors and shareholders are especially concerned with information transparency to control the extent of leverage.

Hypothesis of leverage is as follows:

$\mathrm{H} 2$ : There is a positive association between the firm leverage and the amount of transparency. Sales

Georgian firms those sales are more than 5 million, are obliged to release their accounting information in more details than those with lower sales. They have to present income statement together with the balance sheet and some other financial statements to the Tax authorities, while the companies with the lower sales are obliged to present only income statement tax return files. Hence it follows:

H3. The extent of disclosure is positively related to the firms' sales.

Profitability and Return on equity (ROE)

There is a common suggestion that a firm's willingness to expose data publicly is positively related to the firm's profitability. Singhvi and Desai (1971) definite that higher profitability companies could reveal more information in order to establish its capacity to enhance its supervisory remuneration by enlarging investors' profit. On the other hand, executives those having low profitability will be afraid and demand to disclose low information to outsiders. 
INTERNATIONAL JOURNAL OF ACADEMIC RESEARCH IN ACCOUNTING, FINANCE AND

MANAGEMENT SCIENCES

Vol. 11, No. 1, 2021, E-ISSN: 2225-8329 @ 2021 HRMARS

H4. Profitable firms disclose more information publicly than the companies with low profit.

H5. Companies with higher ROE disclose information publicly than the companies with low profit.

\section{Firm Age}

There are numerous hypothetical foundations to have confidence in that older companies are probable to report more data publicly than the newly established ones. Newly established firms do not provide complete data about their accounting activities and financial positions because they believe that such kind of information may be damaging. Henceforth older companies do not hesitate to reveal their financial reports publicly as they are not afraid of rival companies;

In Georgia old firms are more likely to expose information publicly, maybe because they have been specialized in preparation of financial reporting.

H6: There is an important positive correlation between the firm age and disclosure level of companies.

\section{Liquidity}

Liquidity shows solvency of companies if they can cover their current liabilities in case of necessities. In Georgia liquidity ratio plays an important role is determining a firm's capacity to cover its short-term debts. So, the firms those have low liquidity position have to disclose more financial information to their shareholders and creditors and, it serves as the main tool for measuring the margin of safety that the firm owns to pay off its short-term liabilities.

H7. There is an important positive association between the extent of disclosure and the firm liquidity.

\section{Corporate Governance related variables} Independent Directors

The percentage of independent directors is progressively used as variable in recent analysis. If independent directors perfectly complete their supervision and auditor function, corporate governance is empowered, board efficiency is meaningfully distended, disclosure value is developed and more data publication is awaited (Fama,1980).

H8. There is a positive correlation between the range of transparency and the independent directors.

\section{Board size}

As boar size is enlarged, it is believed that management will be more effective for corporate achievements due to a broad extent of combined knowledge and competences of members that enables them to make more relevant conclusions.

H9. There is a positive correlation between amount of information transparency and the board size and.

\section{Institutional ownership}

Institutional ownership is one of the tools that relate the concerns of investors and supervisors. H10. There is a positive correlation between the institutional ownership and the extent of information transparency. 
INTERNATIONAL JOURNAL OF ACADEMIC RESEARCH IN ACCOUNTING, FINANCE AND

MANAGEMENT SCIENCES

Vol. 11, No. 1, 2021, E-ISSN: 2225-8329 @ 2021 HRMARS

\section{Industry type}

It is generally acknowledged that industrial firms are more probable to reveal more financial information publicly than non-industrial. In Georgia both the manufacturing and non-manufacturing companies are obliged to disclose financial data to tax authorities (that is not public), although accounting reporting of the industrial companies are controlled and checked more carefully and precisely than the service ones, because of its complicated and sophisticated nature.

H11. Industrial companies show a bigger amount of disclosure than non-industrial ones.

\section{Auditor type}

Audit companies are basically classified into large (big 5) and small (not big 5). While small local audit firms function locally, in contract Big audit firms are running almost in all over the world. The big audit firms concerned more for their authority, therefore they are more willing to contact with companies that present financial data publicly. But small local audit firms do not preserve the authority to affect the disclosure process of their customers. Instead, in order to hold their customers, they try to satisfy the requirement of their own customers. They try to satisfy the requirements of their customers in order to hold them.

In Georgia, firms those hire the audit companies within the big 5 are more willing to disclose accounting records publicly than those hiring small audit companies.

H12. The level of disclosure is bigger for the companies that financial information is audited by a big five audit firms.

Table 1 Industrial Breakdown of Companies

\begin{tabular}{|l|l|l|}
\hline & Frequency & Percent \\
\hline Beverage Food & 6 & $12.2 \%$ \\
\hline Paper, printing, Wood & 2 & $4.1 \%$ \\
\hline Petroleum, Chemical, plastic & 2 & $4.1 \%$ \\
\hline Machinery, metal & 16 & $32.7 \%$ \\
\hline Mineral product & 2 & $4.1 \%$ \\
\hline Textile & 4 & $8.2 \%$ \\
\hline Others & 17 & $34.7 \%$ \\
\hline Total & 49 & 100 \\
\hline
\end{tabular}

Source: Author's own calculations.

\section{Univariate Analysis and Findings}

My research sample consists of 56 companies in my research are composed of 22 nonmanufacturing and 28 are manufacturing companies. I employed manufacturing firms or nonmanufacturing firms as dummy variables (INDUST) in the equations. Table 1 shows break down all companies in the sample into seven industry categories.

Table 3 reports firms disclosure scores and average score. Typical, firms print $38 \%$ of voluntary items of their data. The highest disclosure score is 77 and lowest disclosure is 20, and average value is $38 \%$.

Table 2 shows descriptive statistics of independent variables (disclosure variables) and the dependent variable. Most of companies are profitable, nonetheless 10 companies are unprofitable. 
INTERNATIONAL JOURNAL OF ACADEMIC RESEARCH IN ACCOUNTING, FINANCE AND MANAGEMENT SCIENCES

Vol. 11, No. 1, 2021, E-ISSN: 2225-8329 @ 2021 HRMARS

The average return on equity (ROE) is 19\%, which is quite high. Firms in Stock Exchange of Georgia are dominating sector in Georgia. The numbers for firm size (SALES and ASSETS) are also given, average size in terms of assets is 4,505,704 GEL and maximum size in terms of assets is $103,000,000$ GEL.As sales mean is $1,281,903 \mathrm{GEL}$. The average of audit is very weak. Its mean value is $29 \%$, indicating that small number of the firms' statements are audited by Big-4 auditing firms. Leverage ratio figure $37 \%$ on average indicate that the firms are not highly leveraged. That might explain why return on equity ratios are high on average.

Table 2 Descriptive Statistics for All Variables.

\begin{tabular}{|l|l|l|l|l|l|}
\hline & Mean & Median & Maximum & Minimum & Std. Dev. \\
\hline DSCORE & 0.3812 & 0.2812 & 0.7754 & 0.2015 & 0.332651 \\
\hline ASSET & GEL & GEL & GEL & GEL & 16758369 \\
& $4,505,704$ & $1,062,700$ & $103,000,000$ & $55,357.00$ & \\
\hline CURRATIO & 0.455205 & 0.49983 & 0.971172 & 0 & 0.273706 \\
\hline LEVER & 0.372697 & 0.290292 & 0.877925 & 0 & 0.429268 \\
\hline ROE & 0.196916 & 0.073871 & 1.326509 & -0.924235 & 0.456069 \\
\hline SALES & GEL & GEL & GEL & GEL & 2379736 \\
& $1,281,903$ & 360,200 & $9,241,700$ & $9,592.00$ & \\
\hline LAGE & 18.91892 & 20 & 23 & 6 & 4.009561 \\
\hline INDIR & 0.765405 & 0.84 & 1 & 0.23 & 0.266143 \\
\hline BSIZE & 3.459459 & 3 & 10 & 1 & 1.804233 \\
\hline AUDITOR & 0.297297 & 0 & 1 & 0 & 0.463373 \\
\hline
\end{tabular}

The board size moves from 10 to 1 and its average is 3.8 firms are having only 1 or 2 people on the board. $76 \%$ of board members are composed of independent directors. These levels of variables are very high compared to other studies as Chau and Gray (2002) and Uyar et al., (2013). respectively $35 \%$ and $5 \%$. The average age of firms is 19 years. Liquidity ratio illustrate that $45 \%$ of assets are short-term. This ratio is quite high as well, showing no any kind of solvency problems in the firms.

In order to control multicollinearity, Pearson correlation are applied among the explanatory variables. Multicollinearity (also collinearity) appears when two or more independent variables are highly correlated. Consequently, regression will be inconsistent. Correlation and VIF factor of variables are tested in the regression. To solve the multicollinearity, correlated variables should be removed from the model. If there exist two or more factors with a high VIF, removing one from the model will solve the problem of multicollinearty. As a result, three different equations are developed. Table 4 presets the results of association between explanatory variables. Association between ASSET and SALES, BSIZE and ASSET are 0.9052 positive and significant, 0.6149 positive respectively at 5 level significance. Therefore, these two highly associates are not used together.

According to Table 4, the disclosure index does not have significant correlation with majority of variables. It has positive and significant correlation with sales, assets and board size. 
INTERNATIONAL JOURNAL OF ACADEMIC RESEARCH IN ACCOUNTING, FINANCE AND MANAGEMENT SCIENCES

Vol. 11, No. 1, 2021, E-ISSN: 2225-8329 @ 2021 HRMARS

Table 3. Voluntary Disclosure Index of Companies in Georgia (VDINDEX)

\begin{tabular}{|l|l|l|l|}
\hline Company Name & VDINDEX & Company Name & VDINDEX \\
\hline JSC Teliani Valley & $69 \%$ & Isani-Kartu & $29 \%$ \\
\hline JSC Almatea & $37 \%$ & Kutaisi Autoservice Rashi & $34 \%$ \\
\hline JSC Amtse & $49 \%$ & Liberty Consumer & $71 \%$ \\
\hline JSC Andza 94 & $40 \%$ & Maglivmsheni & $31 \%$ \\
\hline JSC Aqati & $34 \%$ & Mamuli & $34 \%$ \\
\hline Avtoshemketebeli & $29 \%$ & Matsne & $43 \%$ \\
\hline Bambus Narti & $40 \%$ & NINO & $31 \%$ \\
\hline Bank of Georgia & $74 \%$ & Oqsino & $43 \%$ \\
\hline Charkhmshenebeli & $43 \%$ & Poti & $43 \%$ \\
\hline Ekrani-Lilo & $31 \%$ & Saktelephonmsheni & $29 \%$ \\
\hline $\begin{array}{l}\text { Caucasus } \\
\text { Infrastructure }\end{array}$ & $\mathbf{3}$ & Saktsivprodukti & $40 \%$ \\
\hline Charkhmshenebeli & $71 \%$ & Samto qimia 2000 & $40 \%$ \\
\hline Elaqtroavtomati & $26 \%$ & Saqpetqmrewvi & $40 \%$ \\
\hline Electric engine plant & $23 \%$ & Saqsashenmetsniereba & $20 \%$ \\
\hline Eleqtroizoliti & $43 \%$ & Sarajishvili & $29 \%$ \\
\hline Hotel Likani & & $\begin{array}{l}\text { Tbilisi School Inventory } \\
\text { Factory }\end{array}$ & $23 \%$ \\
\hline Industria-21 & $37 \%$ & Tbilkhelsatsko & $26 \%$ \\
\hline Industria-Investi & $29 \%$ & Tbillitonnatsarmi & $20 \%$ \\
\hline Janmrteloba & $37 \%$ & Telasi & $69 \%$ \\
\hline Kashanuri & $29 \%$ & $\begin{array}{l}\text { Trading House Kid's } \\
\text { World }\end{array}$ & $31 \%$ \\
\hline Kutaisi Confectionary & $26 \%$ & Uksovadi Ksovilebi & $20 \%$ \\
\hline Waterproject & 0.4 & Disclosure Score & $38 \%$ \\
\hline
\end{tabular}

\section{Pearson Correlation Matrix}

Voluntary disclosure index (DSCORE) unexpectedly has negative, but insignificant correlation with big- 5 auditor firms, current ratio, independent directors and age of firms. Findings in analysis of regressions reveal, coefficient of these variables are insignificant. It means that being a client of 5-big auditor firms does not necessarily enforce companies to reveal more information to public. Correlation of age of firms and independent are contradict with previous studies and expectation. As sample firms in theses get older and more independent, disclosure score is getting less.

I also tested heteroscedanticity, employing White test. The result of $\mathrm{P}$-value (0.9992) is greater than 5 level significance, therefore I accept the null hypotheses $\left(\mathrm{H}_{0}=\mathrm{R}=\mathrm{O}\right.$ (homo)). It is difficult to explain heteroscedasticity. If there is a heteroscedasticity problem, it means that variability of one or more variables is unequally distributed across the range of the values. There are several ways to remove heteroscedasticity. Easy way is to get natural logarithm of dependent variables. White test reported to accept that my variables are normally distributed across the mean. 
INTERNATIONAL JOURNAL OF ACADEMIC RESEARCH IN ACCOUNTING, FINANCE AND

MANAGEMENT SCIENCES

Vol. 11, No. 1, 2021, E-ISSN: 2225-8329 @ 2021 HRMARS

\section{Multivariate Analysis}

I prepared four ordinaries least square (OLS) regression model for all variables. The multiple regression results are reported in Table 5 . The adjusted coefficient of indications (adjusted $\mathrm{R}$ squared) in all four models performed weak indication, referring to $9.9 \%$ in model $1,6.5 \%$ in model $2,10 \%$ in model 3 and $11 \%$ in model 4 of the variation in the dependent variable is described by variation in the explanatory variables.

In model 1 and 3, the effect of sales on voluntary information disclosure level as firm size was analyzed. Results reported no significant relation between SALES and DSCORE in both models. But sign of coefficient is positive in model 1 as expectedly and negative in model 3. Thus, Hypotheses 3 is rejected. This result is contradictory to the finding of (Uyar et al., 2013; Wallace et al, .1994). Size of firms does not affect on disclosure range. It is described as the reason of that small or large firms are not well organized and structured, and not have developed information system and operating activities. All these facts don't make any difference between large and small firms to disclose information. There are no general requirement procedures for non-regulated entities to file or publish their financial statements, in contract to regulated institutions have to publish financial statement with their respective regulators. Another size indicators ASSET does not provide significant relation with DSCORE. But its sign is positive as expected. $\mathrm{H} 1$ Hypotheses regarding firm size is also rejected.

Next tested variable is profitability (ROE) has only model 1 has positive and significant association (0.436) at 1 level significance with voluntary information disclosure (DSCORE). Hence, Hypotheses 4 in association to profitability of firms is accepted in model 1 . But its relation to voluntary disclosure in model 2, 3 and 4 are rejected. According to result of model 2, 3 and 4, these results can be explained as firms in Georgia concern that information disclosure might deteriorate their position in market, by providing more firms' information.

In the second hypothesis, findings show that association between LEVER and DSCORE in model 1 and 2 is negative and significant, but positive relation with DSCORE in model 3 and 4 . Leveraged firms want to reveal less voluntary information as relation result between LEVER and DSCORE shows. Because firms want stakeholders to know solvency of company. In 3 and 4 model doesn't provide significant relationship between these two variables. So, I reject the Hypotheses according to model 1 and 2. This result of variable confirms the finding of (Uyar et al., 2013). It does not support the studies (Chau \& Gray, 2002), where they provide either no significant association or positive association. According to signaling theory, lover leveraged companies want to take attention to their financial structure position by giving less disclosure information to public. In other saying, high leveraged firms do not want to disclose less information for their indebtness so that their image is not suffered 
INTERNATIONAL JOURNAL OF ACADEMIC RESEARCH IN ACCOUNTING, FINANCE AND MANAGEMENT SCIENCES

Vol. 11, No. 1, 2021, E-ISSN: 2225-8329 @ 2021 HRMARS

Table 4. Pearson Correlation Matrix

\begin{tabular}{|c|c|c|c|c|c|c|c|c|c|c|}
\hline & Dscore & Sales & $\begin{array}{l}\text { Asse } \\
\mathrm{t}\end{array}$ & ROE & Lever & Auditor & $\begin{array}{l}\text { Currati } \\
\text { o }\end{array}$ & INDIR & Large & BSIZE \\
\hline Dscore & 1.000 & & & & & & & & & \\
\hline Sales & $\begin{array}{l}0.1277 \\
*\end{array}$ & 1.000 & & & & & & & & \\
\hline Asset & 0.1638 & 0.905 & $\begin{array}{l}1.00 \\
0\end{array}$ & & & & & & & \\
\hline ROE & $\begin{array}{l}0.0183 \\
*\end{array}$ & 0.249 & $\begin{array}{l}0.00 \\
4\end{array}$ & 1.000 & & & & & & \\
\hline Lever & 0.0261 & -0.123 & $\begin{array}{l}- \\
0.10 \\
0\end{array}$ & 0.051 & 1.000 & & & & & \\
\hline Auditor & -0.127 & 0.193 & $\begin{array}{l}0.26 \\
4\end{array}$ & 0.015 & -0.140 & 1.000 & & & & \\
\hline Currati & $\begin{array}{l}- \\
0.0837\end{array}$ & 0.181 & $\begin{array}{l}0.18 \\
6\end{array}$ & -0.080 & -.114 & 0.0637 & 1.000 & & & \\
\hline INDIR & $\begin{array}{l}- \\
0.0597\end{array}$ & $\begin{array}{l}- \\
0.337^{*}\end{array}$ & $\begin{array}{l}- \\
0.23 \\
8\end{array}$ & $\begin{array}{l}- \\
0.383 \\
*\end{array}$ & $\begin{array}{l}- \\
0.074 \\
9\end{array}$ & 0.211 & -0.044 & 1.000 & & \\
\hline Large & -0.056 & $\begin{array}{l}- \\
0.1626\end{array}$ & $\begin{array}{l}- \\
0.36 \\
*\end{array}$ & -0.066 & $\begin{array}{l}- \\
0.049 \\
8\end{array}$ & -0.1159 & -0.122 & $\begin{array}{l}- \\
0.289 \\
7\end{array}$ & 1.000 & \\
\hline BSIZE & $0.332 *$ & $\begin{array}{l}0.3494 \\
*\end{array}$ & $\begin{array}{l}0.61 \\
*\end{array}$ & $\begin{array}{l}0.338 \\
2^{*}\end{array}$ & $\begin{array}{l}- \\
0.026 \\
3\end{array}$ & 0.1976 & -0.268 & $\begin{array}{l}0.041 \\
0\end{array}$ & $\begin{array}{l}- \\
0.167 \\
5\end{array}$ & 1.000 \\
\hline
\end{tabular}

The age variable is not significant. That means that disclosure level is not influenced by age of companies' years. The other many multiple variables are not significant. Probably Georgian firms are more confronted with the obligatory information rather voluntary presentations of information. Hypotheses 6 is rejected. As expected, new companies should obligate to present more information to decrease doubt and increase assurance of stakeholders.

As seen from result of model 1, 2, 3 and 4, board size has significant association with DSCORE. Hence, hypotheses 9 is accepted. But its sign is positive in all models as expected. This can lead that board size is a fact to influence voluntary disclosure level. But findings don't show efficiency of board's working which is more important.

In another hypothesis 8 that measures association between independent director (INDIR) and voluntary disclosure level, no significant association among them are presented. That means that number of independent directors in firms is not a fact to provide more information in Georgian firms. Hence, Hypotheses 8 is rejected. These findings do not support Cheng and Gray (2002) but supports Ho and Wong (2001). As agency theory is concerned, more independent manager in the board of company doesn't help to reduce conflict of interest and corporate governance problems. 
Industry type variable has positive and significant association with DSCORE. In many another research, this variable is not tested. It may be explained as that manufacturing firms are more intended to release more voluntary information. Hence, Hypotheses 11 is accepted.

In the last test report, hypotheses H12 is test to measure the association between AUDITOR and DSCORE.I could not find significant relations among these variables in all models. Being client

Big-4 auditing companies is not a fact to disclose more voluntary information. Therefore, Hypotheses $\mathrm{H} 12$ is rejected. Finding in this test is also supported of findings in the paper of Wallace et al., (1994) and Chau and Gray (2002). This can be interpreted as that majority of firms in list of companies are not clients of Big-4 auditing companies and even if they are clients of them, big auditing firms do only audit information of financial statements

Overall, the findings of current paper present variant result among in all model used. All model shows very low F-ratio, ranging from 1.55 ( $p>0.05$ to 1.28 ( $p>0.05$ ). These tested equations do not support significance of all models. Adjusted $-R$ square values are also very low, ranging from 0.065 to 0.1087 in overall models. As a result of regression models used in the paper, explanatory variables do not explain just $10 \%$ and $6.5 \%$ variation in voluntary disclosure index. 
INTERNATIONAL JOURNAL OF ACADEMIC RESEARCH IN ACCOUNTING, FINANCE AND MANAGEMENT SCIENCES

Vol. 11, No. 1, 2021, E-ISSN: 2225-8329 ๑ 2021 HRMARS

Table 5. Regression results (Asset \& Sales)

\begin{tabular}{|c|c|c|c|c|}
\hline & (Model 1) & (Model 2)(Sales) & $\begin{array}{l}\text { (Model } \\
\text { 3)(Asset) }\end{array}$ & $\begin{array}{c}\text { (Model 4)(Asset } \\
\text { and Sales }\end{array}$ \\
\hline & DSCORE & DSCORE & DSCORE & DSCORE \\
\hline & (OLS) & (OLS) & & \\
\hline \multirow[t]{2}{*}{ ASSET } & $5.84 \mathrm{e}-05$ & $3.42 \mathrm{e}-09$ & & \\
\hline & $(0.32)$ & $(0.41)$ & & \\
\hline \multirow[t]{2}{*}{ SALES } & $4.67 e-08$ & - & $-2.46 \mathrm{e}-08$ & \\
\hline & $(1.10)$ & & $(-0.98)$ & \\
\hline \multirow[t]{2}{*}{ ROE } & $0.436 * *$ & 0.347 & 0.139 & -0.0998 \\
\hline & $(1.76)$ & $(1.42)$ & $(0.96)$ & $(-0.71)$ \\
\hline \multirow[t]{2}{*}{ LEVER } & $-0.272^{*}$ & $-0.246^{*}$ & 0.159 & 0.148 \\
\hline & $(-2.51)$ & $(-2.65)$ & $(1.25)$ & $(1.18)$ \\
\hline \multirow[t]{2}{*}{ AUDITOR } & 0.334 & 0.328 & -0.167 & -0.168 \\
\hline & $(1.58)$ & $(1.52)$ & $(-1.34)$ & $(-1.35)$ \\
\hline \multirow[t]{2}{*}{ CURRATIO } & -0.322 & -0.256 & -0.0159 & -0.0452 \\
\hline & $(-0.91)$ & $(-0.71)$ & $(-0.08)$ & $(-0.22)$ \\
\hline \multirow[t]{2}{*}{ INDUST } & $0.409^{*}$ & $0.388 * *$ & -0.229 & -0.211 \\
\hline & $(2.11)$ & $(1.97)$ & $(-2.02)$ & $(-1.88)$ \\
\hline \multirow[t]{2}{*}{ INDIR } & 0.446 & 0.372 & -0.183 & -0.139 \\
\hline & $(1.04)$ & $(0.87)$ & $(-0.73)$ & $(-0.56)$ \\
\hline \multirow[t]{2}{*}{ LAGE } & 0.0326 & 0.0324 & -0.0202 & -0.0170 \\
\hline & $(1.27)$ & $(1.11)$ & $(-1.34)$ & $(-1.16)$ \\
\hline \multirow[t]{2}{*}{ BSIZE } & $0.152^{*}$ & $0.139 * *$ & $0.0846^{*}$ & $0.0698^{*}$ \\
\hline & $(2.44)$ & $(2.03)$ & $(2.31)$ & $(2.09)$ \\
\hline \multirow[t]{2}{*}{ Intercept } & -0.0822 & -0.0308 & $1.109^{*}$ & $1.034^{*}$ \\
\hline & $(-0.10)$ & $(-0.04)$ & $(2.40)$ & $(2.27)$ \\
\hline F-value & 1.44 & 1.28 & 1.48 & 1.55 \\
\hline Adjusted $R^{2}$ & 0.0996 & 0.065 & 0.1077 & 0.1087 \\
\hline Significance & 0.2198 & 0.2923 & 0.2044 & 0.1855 \\
\hline
\end{tabular}

$t$ statistics in parentheses ${ }^{*} p<0.05,{ }^{* *} p<0.01,{ }^{* * *} p<0.001$

\section{Conclusions}

In order to retain high quality and transparent financial information of firms and to hold confidence of creditors and investors for getting needed funds to growth, the results of findings 
INTERNATIONAL JOURNAL OF ACADEMIC RESEARCH IN ACCOUNTING, FINANCE AND MANAGEMENT SCIENCES

Vol. 11, No. 1, 2021, E-ISSN: 2225-8329 @ 2021 HRMARS

indicate companies should comply with regulatory makers and rule in the country and provide voluntary information about firms to investor and creditors. Georgia, in this sense, has not yet achieved important regulation and structure. Lack of readily available financial information prevent decision-making, lowers the quality of underwriting and affects the risk management process of stakeholders, like investors, creditors and international fund providers. As seen from results of all regression, due to lack of information provided there is a significant association between dependent variable (DSCORE) and all explanatory variables. This significance might be better and consistent with finding in other research papers, if some other detrimental variables included into regressions. But, as seen from literature review, explanatory variables in this paper are drawn mostly from other papers.

Results report that Georgian firms' disclosure level is at very low level. Lacking of corporate governance practice and enhanced capital market contributes a lot to the damaging of voluntary disclosure levels of firms. As a result, it is needed to enhance regulation and practice of information disclosure standards to average level or even higher level.

In addition, this research presents some important indication for regulators, auditors, firms and investors. All stakeholders in business world has important part in developing and enhancing the disclosure practices of firms and transparency of their activities. In addition, establishing of capital market board and awareness of firms in Georgia to present more information about their actives make having international fund easily as well as funds from domestic providers. Capital market should be enhanced and functioned more effectively, so that many idle money flows to firm's needs.

\section{Limitations and Further Research}

Since this paper was conducted only in the list companies of Georgian stock exchange, which is not so much active. This is one of the papers conducted in the Georgian list companies. Therefore, its contribution to Georgian literature is essential and important. Because, all paper on this topic are examined in developed countries, there is scarcity of literature in post-soviet countries like Georgia. Due to lack of information and data. The finding of the research is really of great interest to the shareholders' society that enable them to assess the level of disclosure by Georgian firms and to define alteration of disclosure according to the firm characteristics. Furthermore, this research is conducted in all segment of industries listed in stock exchange. In the future, I aim to sequence my sample in specific sectors and renew my study. Secondly, time used in the paper is only point in time. In further studies, longitudinal studies covering different times can be conducted and adding more variables such as press releases, websites and social media which all may present interesting results.

\section{References}

Berradino, J. F. (2001). Corporate Governance on the agenda. South China Moring Post, April 16.

Brogia, F. (2005). Corporate Governance and transparency role of disclosure. How prevent financial scandals and crimes. American University, Washington D.C, 27-28

Cadbury, A. (1992). The financial aspect of corporate governance. Gee professional publishing, London

Camfferman, K., and Cooke, T. (2002). An analysis of disclosure in the annual reports of UK and Dutch companies. Journal of international accounting, 1(1),1-28. DOI: 10.2308/jiar.2002.1.1.3

Chau, G. K., and Gray, S. J. (2002).Ownership structure and corporate voluntary disclosure in Hong Kong and Singapore. The International Journal of Accounting, 37(2), pp 247-264; 
INTERNATIONAL JOURNAL OF ACADEMIC RESEARCH IN ACCOUNTING, FINANCE AND

MANAGEMENT SCIENCES

Vol. 11, No. 1, 2021, E-ISSN: 2225-8329 @ 2021 HRMARS

https://EconPapers.repec.org/RePEc:eee:accoun:v:37:y:2002:i:2:p:247-265

Chow, C., \& Wong-Boren, A. (1987). Voluntary Financial Disclosure by Mexican Corporations. The Accounting Review, 62(3), 533-541. Retrieved February 5, 2021, from http://www.jstor.org/stable/247575

Cooke,T. E. (1989). Voluntary corporate disclosure by Swedish companies. Journal of International FinancialManagementandAccounting,1(2),171-195.

extension://bfdogplmndidlpjfhoijckpakkdjkkil/pdf/viewer.html?file=https\%3A\%2F\%2Fciteseer x.ist.psu.edu\%2Fviewdoc\%2Fdownload\%3Fdoi\%3D10.1.1.457.722\%26rep\%3Drep1\%26type\% 3Dpdf

Fama, E. (1980). Agency Problems and the Theory of the Firm. Journal of Political Economy, 88(2), 288-307. Retrieved March 17, 2021, from http://www.jstor.org/stable/1837292

Francis, J., Khurana, I., \& Raynolde Pereira. (2005). Disclosure Incentives and Effects on Cost of Capital around the World. The Accounting Review, 80(4), 1125-1162. Retrieved February 5, 2021, from http://www.jstor.org/stable/4093119

Jensen, M. C., and Meckling, W. H. (1976). Theory of the Firm: Managerial behavior, agency costs and ownership structure. Journal of Financial Economics,3(4),305-360. https://doi.org/10.1016/0304-405X(76)90026-X.

Knutson, P. (1992). Financial reporting in the 1990's and beyond: An Executive Summary. Financial Analysts Journal, 48(6), 21-23. https://doi.org/10.2469/faj.v48.n6.21

Lang, M., \& Lundholm, R. (1993). Cross-Sectional Determinants of Analyst Ratings of Corporate Disclosures. Journal of Accounting Research, 31(2), 246-271. https://doi.org/10.2307/2491273

McKinnon, J. L., \& Dalimunthe, L. (1993). Voluntary disclosure of segment information by Australian diversified companies. Accounting and Finance, 33 (1), 33-50.

https://doi.org/10.1111/j.1467-629X.1993.tb00192.x

Patelli, L. \& Prencipe, A. (2007). The Relationship between Voluntary Disclosure and Independent Directors in the Presence of a Dominant Shareholder, European Accounting Review, 16:1, 533, DOI: $10.1080 / 09638180701265820$

Poshakwale, S., \& Courtis, J. (2005). Disclosure Level and Cost of Equity Capital: Evidence from the Banking Industry. Managerial and Decision Economics, 26(7), 431-444. Retrieved February 5, 2021, from http://www.jstor.org/stable/25151401

Simon, S. M. Ho., and Wong, K. S. (2001). A study of the relationship between corporate governance structures and the extent of voluntary disclosure. Journal of International Accounting, Auditing and Taxation,10(2), 139-156. https://doi.org/10.1016/S1061-9518(01)00041-6.

Singhvi, S., Desai, H. (1971). An empirical analysis of the quality of corporate financial disclosure. The Accounting Review, 469(1),129-138. https://www.jstor.org/stable/243894

Uyar, A., Merve K., Bayyurt, N. (2013). Association between firm characteristics and corporate voluntary disclosure: Evidence from Turkish listed companies. Intangible Capital, 9(4), 10801112. DOI: $10.3926 /$ ic.439

Wallace, R. S. O., Naser, K., and Mora, A. (1994). The relationship between the comprehensiveness of corporate annual reports and firm characteristics and in Spain. Accounting and Business Research, 25(97), 41-53. https://doi.org/10.1080/00014788.1994.9729927 www.frc.org.uk\%2Fgetattachment\%2F9c19ea6f-bcc7-434c-b481-f2e29c1c271a\%2FTheFinancial-Aspects-of-Corporate-Governance-(the-Cadbury-Code).pdf 